
\title{
$\begin{array}{ll}\text { Research Square } & \begin{array}{l}\text { Preprints are preliminary reports that have not undergone peer review. } \\ \text { They should not be considered conclusive, used to inform clinical practice, } \\ \text { or referenced by the media as validated information. }\end{array}\end{array}$
}

\section{Spatio-temporal variations of lower tropospheric pollutants and their relation with meteorological factors in Karachi, Pakistan}

Dilshad Ahmed

Sindh Environmental Protection Agency, Karachi, Pakistan

Zafar lqbal Shams ( $\nabla$ zishams@uok.edu.pk)

University of Karachi, Karachi, Pakistan https://orcid.org/0000-0002-4564-4366

Moinuddin Ahmed

Indiana University

Muhammad Fahim Siddique

University of Karachi

\section{Research Article}

Keywords: Air Pollution, Meteorological Factor, Karachi, Correlation, Fuel Type

Posted Date: December 1st, 2021

DOI: https://doi.org/10.21203/rs.3.rs-1077688/v1

License: (c) (i) This work is licensed under a Creative Commons Attribution 4.0 International License. Read Full License 


\section{Abstract}

Despite being one of the most populated cities globally, the air quality of Karachi is hardly ever comprehended. The present paper investigates the outdoor concentrations of 10 air pollutants, viz. $\mathrm{NO}, \mathrm{NO}_{2}, \mathrm{NOx}, \mathrm{SO}_{2}, \mathrm{CO}, \mathrm{O}_{3}, \mathrm{CH}_{4}$, methane carbon, non-methane hydrocarbons, and total hydrocarbons at three different city sites, viz., Sohrab Goth, Defense Housing Authority, and North Nazimabad. The results demonstrate that these pollutants severely affected the city's air quality. The annual mean concentrations of both $\mathrm{NO}_{2}$ and $\mathrm{SO}_{2}$ exceeded the $\mathrm{WHO}$ guidelines at some study sites. The city experiences varied concentrations of major air pollutants because three types of fuel, viz. diesel, gasoline, and compressed natural gas, operate the motor vehicles in this conurbation. The study also correlates the various air pollutants with each other and with various meteorological factors. All the three oxides of nitrogen are statistically associated at all three sites with one another, with $\mathrm{SO}_{2}$ at Defense Housing Authority, with $\mathrm{CO}$ at North Nazimabad, and with meteorological factors at Sohrab Goth and Defense Housing Authority. Carbon monoxide is statistically associated with the meteorological factors only at North Nazimabad. The study suggests that higher air pollution in the city is due to the adoption of lenient vehicular emission standards because stringent emission standards cannot be adopted due to the non-availability of low or zero sulfur fuel. Moreover, ineffective regulation of exiting standards also contributes to higher vehicular emissions in the city.

\section{Introduction}

Ambient air pollution is a foremost global environmental concern in the urban areas of developing countries (Li et al., 2019). According to statistics released by the World Health Organization (2016), which covered 3000 cities of more than a hundred thousand inhabitants from 103 low and middle-income countries revealed that $98 \%$ of them exceed the WHO air quality guidelines. Moreover, the air quality levels of $91 \%$ of human-populated areas of the world do not meet WHO guidelines. The ambient air pollution generally exceeds the WHO air quality guidelines in Pakistan, India, China, and Bangladesh.

The high-income countries have substantially improved the air quality of their cities over the last few decades by regulatory interventions and the adoption of advanced emission control technologies in their motor vehicles (Crippa et al., 2015). The developing countries are struggling to control the emissions from the combustion process of motor vehicles, power generation, domestic burning, and heating. These air pollutants cause many human diseases, particularly cancer, cardiovascular and pulmonary diseases (Turner et al., 2020; Namvar et al., 2020) that lead to millions of premature human deaths across the globe (Lelieveld et al., 2015).

Outdoor air pollution begets 4.2 million premature deaths annually due to heatstroke, cardiovascular and respiratory diseases. More than two-thirds of them expire prematurely in Southeast Asia and Western Pacific (WHO 2021). According to them, 22,000 adults breathe their last prematurely every year in addition to 163,432 DALYs (disability-adjusted life years) due to outdoor air pollutants in Pakistan. The WHO Health Observatory computed that about 25 deaths per hundred thousand expire due to outdoor air pollution in this country. These figures may be much higher due to infrequent and limited studies. Lelieveld et al. (2015) revealed that about 3.3 million expire prematurely worldwide in 2010 due to outdoor air pollutants, estimated to increase to 6.5 million by 2050 .

Li et al. (2018) reported an association between the ambient carbon monoxide and hospitalization of the people in Beijing for coronary heart diseases. They found a positive relationship between carbon monoxide levels and heart failure. The ambient ozone instigates chronic obstructive pulmonary ailment and cardiopulmonary mortality (Khaniabadi et al., 2017; Zhang et al., 2019). $\mathrm{PM}_{2.5}$ (particulate matter < 2.5 $\mu \mathrm{m}$ ) triggers the ischaemic cardiac disease, cerebrovascular disease, acute lower respiratory illness, chronic obstructive pulmonary ailment, in addition to pulmonary cancer (Hayes et al. 2020).

Furthermore, ambient air pollution jeopardizes the sustainable development of society (Zhao et al. 2018). Haze pollution significantly reduces the sustainable economic development of any region. For instance, on average, an upsurge of $5 \mu \mathrm{g} / \mathrm{m}^{3}$ in $\mathrm{PM}_{2.5}$ levels may cause a decline of around $2500 \mathrm{Yuan}$ in Gross Domestic Products per capita in China (Hao et al., 2018).

Consequently, the developed countries started to monitor ambient air pollution a few decades back (Crippa et al., 2015), followed by the developing countries to address the apprehension regarding urban air pollution (Gulia et al. 2020; Zhang et al. 2020; Guttikunda et al. 2019; Hashmi et al. 2018; Jan et al. 2017; Wu et al. 2017; Chen et al. 2007; Barletta et al. 2002; Shams and Beg 2001). Many researchers investigated the correlations between meteorological factors and outdoor air pollutants across the globe (Kayes et al., 2019; Zhang et al., 2015; Karagiannidis et al., 2015; Jassim et al., 2018; Kalisa et al., 2018; He et al., 2017; Pearce et al. 2011).

Various studies divulged the outdoor air quality of Karachi. For instance, Barletta et al. (2002) investigated the mixing ratios of 72 air pollutants, mainly methane and non-methane hydrocarbons of the city atmosphere. Jan et al. (2017) correlated outdoor air pollutants of Karachi, and Hashmi et al. (2018) classified the study sites of the same city based on their air quality index. Shams and Beg (2001) monitored ambient carbon monoxide in the streets of the metropolitan area. Bibi et al. (2017) investigated the relationships of black carbon with meteorological parameters in an urban area. Ali et al. (2020) studied aerosol trends over 12 urban neighborhoods of Pakistan and tried to develop their links with meteorological factors. Studies regarding the correlations between meteorological factors and outdoor air pollutants are uncommon in Karachi. It is one of the densest cities in the world (City Mayors Statistics 2018). The effect of meteorological factors on some air pollutants is not yet clearly understood. Therefore, the present study investigates the ambient concentrations of ten different air pollutants at three designated sites of the city and their relationship with meteorological parameters.

\section{Materials And Methods Study Sites}

Karachi is the most populous city in Pakistan and the third most populous city on earth (City Mayors Statistics 2018). It is an industrial nucleus of the country. It spans over an extent of $3530 \mathrm{~km}^{2}$ (Karachi Metropolitan Corporation 2021). It lies along the coastline of the Arabian Sea, between $24^{\circ} 43^{\prime} \mathrm{N}$ to $25^{\circ} 38^{\prime} \mathrm{N}$ and 
$66^{\circ} 43^{\prime} \mathrm{E}$ to $67^{\circ} 33^{\prime}$ at an altitude of eight meters. The city has a hot arid desert climate (Kottek et al. 2006), distinguished by little precipitation (250mm annual). The city experiences extended warm summer seasons (March - October) with a mean daily temperature between $25^{\circ} \mathrm{C}$ to $35^{\circ} \mathrm{C}$ and mild winter seasons (November - February) with a mean daily temperature between $18{ }^{\circ} \mathrm{C}$ to $20^{\circ} \mathrm{C}$. The high relative humidity and high southwestern wind in monsoon seasons (June to September) are common in the city. The wind velocity exceeds $19 \mathrm{~km} / \mathrm{hr}$ during monsoon seasons. Three designated sites, viz., North Nazimabad, Defense Housing Authority, and Sohrab Goth were selected for the present study.

\section{North Nazimabad, Karachi}

North Nazimabad is a residential area of middle-income inhabitants (FBR 2019) with commercial activities, namely, shopping malls, restaurants, hospitals, gas stations, schools, and colleges. It is located in the central north of the city, $20 \mathrm{~km}$ away from the Arabian Sea. This study area has an air quality monitoring station 10 meters above the ground on a building located at 24ه57'05.4" N and 67ه03'42.8" E.

\section{Defense Housing Authority, Karachi}

Defense Housing Authority, commonly known as DHA, is predominantly a residential area of high-income inhabitants (FBR 2019). The neighborhoods have commercial activities that include towering shopping plazas, restaurants, hospitals, gas stations, schools, and colleges. It is located in the southern part of the city, very close to the Arabian Sea. It is a well-planned and well-developed area of Karachi. The study area has an air quality monitoring station 7 meters above the ground on a building located at 24ه49'52.9" $\mathrm{N}$ and 67ه03'35.5" E.

\section{Sohrab Goth (SG), Karachi}

Sohrab Goth comprises commercial, residential, and industrial areas. The main road of this area connects the city to the rest of the country through a motorway. For that reason, the neighborhood has one of the busiest roads. The road carries all types of motor vehicles round the clock. Nonetheless, dieselpowered heavy motor vehicles, like 10 -wheeler trucks and buses, dominate the road even at night. The air quality monitoring mobile station was located at $24^{\circ}$ $56^{\prime} 42.10^{\prime \prime} \mathrm{N}$ and $67^{\circ} 05^{\prime} 08.10^{\prime \prime} \mathrm{E}$ on the main street of Sohrab Goth to determine the ambient air quality of the area.

\section{Experimental:}

The ambient parameters were monitored continuously at all three designated sites of the city by the Air Quality Monitoring Station, equipped with Horiba AP370 series viz. APNA-370, APHA-370, APMA-370, APSA-370 and APOH-370. A station was at the rooftop of the buildings at each of the two sites, namely, DHA and North Nazimabad, and the third station having the equipment of the same AP-370 series was at the rooftop of a mobile van for data collection at Sohrab Goth.

APNA-370 continuously measured the ambient concentrations of nitric oxide (NO), nitrogen dioxide $\left(\mathrm{NO}_{2}\right)$, and nitrogen oxides ( $\mathrm{NO}$ ). $\mathrm{APHA}-370$ measured ambient concentration of methane $\left(\mathrm{CH}_{4}\right)$, non-methane hydrocarbons (NMHC), and total hydrocarbons (THC), and while APSA-370, APMA-370, and APOH-370 measured sulfur dioxide $\left(\mathrm{SO}_{2}\right)$, carbon monoxide $(\mathrm{CO})$, and ozone $\left(\mathrm{O}_{3}\right)$. These instruments measured daily all the parameters. The Central Processing Unit (CPU) connected all these instruments. The devices installed outside the station simultaneously measured the meteorological parameters.

Later, the monthly averages of every parameter were transferred to an Excel sheet for analysis. Analysis of Variance was executed to divulge the statistical differences of ambient concentrations of different parameters among the city's three sites. Pearson's correlation was performed to determine the correlations among each other. The box and whisker plots illustrate The medians, first and third quartiles, minimum and maximum concentrations of all the parameters.

The AP-370 series has a built-in calibration solenoid valve for calibration simply by connecting the calibration gas. APNA-370 works on cross-flow modulation, reduced pressure chemiluminescence, APMA-370 operates on cross-flow modulation, non-dispersive infrared absorption technology, APSA-370 functions on UV fluorescence, and APOH-370 works on Non-dispersive ultraviolet-absorption method.

\section{Results}

Figure 2 demonstrates the annual concentrations of nitrogen dioxide $\left(\mathrm{NO}_{2}\right)$ and sulfur dioxide $\left(\mathrm{SO}_{2}\right)$ in the ambient air of Sohrab Goth, DHA, and North Nazimabad, their averages, and the World Health Organization guidelines for their maximum permissible limits.

Figures 3 - 12 reveal the ambient concentrations of eight primary and two secondary air pollutants during twelve months at three designated locations of Karachi, namely Sohrab Goth, DHA, and North Nazimabad. The ambient concentrations of four primary air pollutants, viz., nitric oxide, nitrogen oxides, sulfur dioxide, and carbon monoxide (CO) differed significantly among three designated sites ( $<$ < 0.001$)$. Nitrogen dioxide, a secondary pollutant, significantly differed among these three sites $(p<0.05)$. The ambient concentrations of nitric oxide, nitrogen dioxide, and carbon monoxide in North Nazimabad were lower than Sohrab Goth and DHA $(p<0.01)$. The concentration of nitrogen dioxide $(p<0.05)$ and sulfur dioxide $(p<0.001)$ in the ambient air of Sohrab Goth were significantly higher than those at DHA and North Nazimabad.

However, the ambient concentrations of four primary air pollutants, viz., methane $\left(\mathrm{CH}_{4}\right)$, non-methane hydrocarbons ( $\left.\mathrm{NMCH}\right)$, total hydrocarbons and methane carbon, and ozone, a secondary air pollutant, did not differ significantly among Sohrab Goth, DHA, and North Nazimabad.

Nitric oxide revealed its highest ambient concentration $\left(90.4 \mu \mathrm{g} / \mathrm{m}^{3}\right)$ in November at Sohrab Goth and its lowest concentration $\left(8.22 \mu \mathrm{g} / \mathrm{m}^{3}\right)$ in May at North Nazimabad (Fig. 3). Ambient nitrogen dioxide divulged the highest concentration $\left(109.33 \mu \mathrm{g} / \mathrm{m}^{3}\right)$ in January at DHA, and its lowest concentration (17.54 $\mu \mathrm{g} / \mathrm{m}^{3}$ ) was in February at North Nazimabad (Fig. 4). Nitrogen oxides demonstrated their highest concentration (113 ppb) in December at Sohrab Goth, while 
the lowest concentration (17 ppb) was in June at North Nazimabad (Fig. 5). Ozone showed its highest ambient concentration (48.78 $\left.\mu \mathrm{g} / \mathrm{m}^{3}\right)$ in April at DHA and the lowest concentration $\left(9.41 \mu \mathrm{g} / \mathrm{m}^{3}\right)$ in August at the very same location (Fig. 6).

Sulfur dioxide showed the highest ambient concentration $\left(171.18 \mu \mathrm{g} / \mathrm{m}^{3}\right)$ at Sohrab Goth in April, and its lowest concentration $\left(7.2 \mu \mathrm{g} / \mathrm{m}^{3}\right)$ was in June in the air of DHA (Fig. 7). Carbon monoxide revealed its highest ambient concentrations $\left(1.7 \mu \mathrm{g} / \mathrm{m}^{3}\right)$ at Sohrab Goth in July, while its lowest concentration ( 0.33 $\mu \mathrm{g} / \mathrm{m}^{3}$ ) was in June in the air of North Nazimabad (Fig. 8).

Methane demonstrated the highest concentration $\left(6,527.5 \mu \mathrm{g} / \mathrm{m}^{3}\right)$ at DHA in July (Fig. 10). Its lowest concentrations with insignificant variation were in April and May at all three sites. The methane concentration ranged from $1,586.1 \mu \mathrm{g} / \mathrm{m}^{3}$ to $6,527.5 \mu \mathrm{g} / \mathrm{m}^{3}$ at three different locations. Non-methane hydrocarbons showed their highest concentration (3870 ppb) in February at Sohrab Goth. The lowest concentration (502 ppb) was noted in April at the same location (Fig. 11).

The total hydrocarbons recorded their highest concentration $(10,245 \mathrm{ppb})$ in October at Sohrab Goth (Fig. 12), the greatest concentration among all the ten pollutants at all the designated sites. The concentration of total hydrocarbons ranged from 2,398 ppb to 10,245 ppb in the ambient air at these locations. Its lowest concentration was found in February in the troposphere of North Nazimabad, while Sohrab Goth recorded the highest concentration in October. As a whole, total hydrocarbons, methane, and non-methane hydrocarbons were higher, followed by carbon monoxide and sulfur dioxide compared to the other five air pollutants.

Figure 13 reveals the Box-and-Whisker plots of six air pollutants: $\mathrm{NO}, \mathrm{NO}_{2}, \mathrm{NOx}, \mathrm{SO}_{2}, \mathrm{O}_{3}$, and methane carbon at three different designated sites of the city. The line that divides black and gray boxes is the median of the pollutant. The upper quartile is by the upper end of the black box, and the lower quartile is indicated by the lower end of the gray box. Minimum and maximum values are shown by thin bars. Figure 14 divulges the plots of three air pollutants, namely methane, non-methane hydrocarbons, and total hydrocarbons. Figure 15 shows the box plots of only carbon monoxide. The plots are displayed in 3 different figures due to huge concentration differences.

Sohrab Goth revealed the highest median concentrations of $\mathrm{CO}, \mathrm{NO}, \mathrm{NO}_{2}, \mathrm{NOx}, \mathrm{SO}_{2}$, and methane carbon, while DHA demonstrated the highest median concentrations of methane, non-methane hydrocarbons, and total hydrocarbons. North Nazimabad showed the highest median concentrations of only ozone among the three designated sites.

North Nazimabad demonstrated the lowest median values of $\mathrm{CO}, \mathrm{NO}, \mathrm{NO}_{2}, \mathrm{NOx}, \mathrm{SO}_{2}, \mathrm{CH}_{4}$, total hydrocarbons, and Sohrab Goth revealed the lowest median concentration of ozone and non-methane hydrocarbons. DHA showed the lowest median concentration of only methane carbon among the three designated sites of the city. As a whole, total hydrocarbons demonstrated the greatest median concentration, while methane carbon revealed the lowest median concentration among the ten air pollutants.

Tables 1 - 3 present Pearson's Correlations to demonstrate the association of different ambient air pollutants with each other and with different meteorological parameters at three designated sites of the city. All the oxides of nitrogen, viz. $\mathrm{NO}, \mathrm{NO}_{2}$ and $\mathrm{NOx}$ demonstrated a positive correlation with each other at all the designated sites. They divulged a highly positive correlation $(p<0.001)$ with each other and a negative correlation with air temperature, wind velocity and direction, and relative humidity at Sohrab Goth and DHA. They showed a positive correlation with ambient carbon monoxide at DHA and North Nazimabad. They revealed a positive correlation with carbon monoxide at DHA and North Nazimabad. They were positively associated with methane carbon only at Sohrab Goth (Table 1). They demonstrated a negative correlation with radiation at Sohrab Goth and North Nazimabad. 
Table 1

Pearson's Correlation among Different Parameters at Sohrab Goth

\begin{tabular}{|c|c|c|c|c|c|c|c|c|c|c|c|c|}
\hline & $\begin{array}{l}\text { Nitric } \\
\text { Oxide }\end{array}$ & $\begin{array}{l}\text { Nitrogen } \\
\text { Dioxide }\end{array}$ & $\begin{array}{l}\text { Nitrogen } \\
\text { Oxides }\end{array}$ & Methane & $\begin{array}{l}\text { Non- } \\
\text { methane } \\
\text { HCs }\end{array}$ & $\begin{array}{l}\text { Total } \\
\text { Hydrocarbons }\end{array}$ & $\begin{array}{l}\text { Carbon } \\
\text { Monoxide }\end{array}$ & $\begin{array}{l}\text { Sulfur } \\
\text { Dioxide }\end{array}$ & Ozone & $\begin{array}{l}\text { Methane } \\
\text { Carbon }\end{array}$ & $\begin{array}{l}\text { Wind } \\
\text { Speed }\end{array}$ & $\begin{array}{l}\text { Wine } \\
\text { Direr }\end{array}$ \\
\hline $\begin{array}{l}\text { Nitrogen } \\
\text { Dioxide }\end{array}$ & 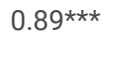 & & & & & & & & & & & \\
\hline $\begin{array}{l}\text { Nitrogen } \\
\text { Oxides }\end{array}$ & $0.86^{\star \star \star}$ & $0.83^{\star \star \star}$ & & & & & & & & & & \\
\hline Methane & $0.59 *$ & 0.44 & 0.48 & & & & & & & & & \\
\hline $\begin{array}{l}\text { Non-methane } \\
\text { HCs }\end{array}$ & 0.00 & -0.12 & -0.19 & 0.46 & & & & & & & & \\
\hline $\begin{array}{l}\text { Total } \\
\text { Hydrocarbons }\end{array}$ & 0.57 & 0.38 & 0.31 & 0.24 & -0.10 & & & & & & & \\
\hline $\begin{array}{l}\text { Carbon } \\
\text { Monoxide }\end{array}$ & -0.05 & 0.19 & 0.15 & 0.06 & -0.34 & -0.19 & & & & & & \\
\hline $\begin{array}{l}\text { Sulfur } \\
\text { Dioxide }\end{array}$ & 0.12 & 0.33 & 0.36 & -0.35 & -0.22 & -0.42 & -0.01 & & & & & \\
\hline Ozone & -0.35 & -0.18 & -0.20 & -0.20 & -0.24 & -0.40 & $0.68^{*}$ & -0.08 & & & & \\
\hline $\begin{array}{l}\text { Methane } \\
\text { Carbon }\end{array}$ & $0.72^{\star \star}$ & $0.60 *$ & $0.60 *$ & $0.70 *$ & 0.38 & 0.55 & -0.27 & -0.02 & $-0.63^{*}$ & & & \\
\hline Wind Speed & $-0.82^{\star \star \star}$ & $-0.77^{\star \star}$ & $-0.75^{\star \star}$ & $-0.62^{\star}$ & -0.20 & -0.31 & 0.13 & -0.34 & $0.60 *$ & $-0.81^{\star \star}$ & & \\
\hline $\begin{array}{l}\text { Wind } \\
\text { Direction }\end{array}$ & $-0.77^{\star \star}$ & -0.78 ** & $-0.76^{\star \star}$ & -0.41 & 0.02 & -0.39 & 0.01 & -0.24 & 0.16 & $-0.69 *$ & $0.57 *$ & \\
\hline $\begin{array}{l}\text { Air } \\
\text { Temperature }\end{array}$ & $-0.69 *$ & $-0.72^{\star \star}$ & $-0.60 *$ & $-0.62^{\star}$ & -0.44 & -0.19 & 0.20 & -0.31 & 0.42 & $-0.86^{\star \star \star}$ & $0.82^{\star \star \star}$ & 0.75 \\
\hline $\begin{array}{l}\text { Relative } \\
\text { Humidity }\end{array}$ & $-0.72^{\star \star}$ & $-0.73^{* \star}$ & $-0.61^{\star}$ & $-0.65^{\star}$ & -0.42 & -0.19 & 0.19 & -0.32 & 0.56 & $-0.84^{\star \star \star}$ & $0.94 * \star \star$ & 0.61 \\
\hline Radiation & $-0.91^{\star \star \star}$ & $-0.72^{\star \star}$ & $-0.73^{\star *}$ & -0.52 & 0.22 & $-0.71 \star \star$ & 0.01 & 0.12 & 0.28 & -0.53 & $0.64^{*}$ & 0.56 \\
\hline
\end{tabular}


Table 2

Pearson's Correlation among Different Parameters at Defense Housing Authority (DHA)

\begin{tabular}{|c|c|c|c|c|c|c|c|c|c|c|c|c|}
\hline & $\begin{array}{l}\text { Nitric } \\
\text { Oxide }\end{array}$ & $\begin{array}{l}\text { Nitrogen } \\
\text { Dioxide }\end{array}$ & $\begin{array}{l}\text { Nitrogen } \\
\text { Oxides }\end{array}$ & Methane & $\begin{array}{l}\text { Non- } \\
\text { Methane } \\
\text { HCs }\end{array}$ & $\begin{array}{l}\text { Total } \\
\text { Hydrocarbons }\end{array}$ & $\begin{array}{l}\text { Carbon } \\
\text { monoxide }\end{array}$ & $\begin{array}{l}\text { Sulfur } \\
\text { dioxide }\end{array}$ & Ozone & $\begin{array}{l}\text { Methane } \\
\text { Carbon }\end{array}$ & $\begin{array}{l}\text { Wind } \\
\text { velocity }\end{array}$ & $\begin{array}{l}\text { Win } \\
\text { Dire }\end{array}$ \\
\hline $\begin{array}{l}\text { Nitrogen } \\
\text { Dioxide }\end{array}$ & $0.87 * \star \star$ & & & & & & & & & & & \\
\hline $\begin{array}{l}\text { Nitrogen } \\
\text { Oxides }\end{array}$ & $0.92^{\star \star \star}$ & $0.83^{\star \star \star}$ & & & & & & & & & & \\
\hline Methane & 0.56 & 0.48 & 0.52 & & & & & & & & & \\
\hline $\begin{array}{l}\text { Non-Methane } \\
\text { HCs }\end{array}$ & -0.20 & -0.25 & -0.15 & -0.08 & & & & & & & & \\
\hline $\begin{array}{l}\text { Total } \\
\text { Hydrocarbons }\end{array}$ & $0.59 *$ & $0.63^{*}$ & 0.50 & 0.10 & -0.24 & & & & & & & \\
\hline $\begin{array}{l}\text { Carbon } \\
\text { Monoxide }\end{array}$ & $0.64^{\star}$ & $0.59 *$ & $0.68^{*}$ & 0.40 & -0.25 & 0.51 & & & & & & \\
\hline $\begin{array}{l}\text { Sulfur } \\
\text { Dioxide }\end{array}$ & $0.79 * \star$ & $0.93^{\star \star \star}$ & $0.78^{\star \star *}$ & 0.44 & -0.19 & 0.49 & 0.43 & & & & & \\
\hline Ozone & 0.02 & 0.22 & -0.06 & -0.32 & -0.28 & -0.04 & -0.18 & 0.38 & & & & \\
\hline $\begin{array}{l}\text { Methane } \\
\text { Carbon }\end{array}$ & 0.22 & 0.27 & 0.22 & 0.28 & -0.56 & 0.45 & 0.17 & 0.26 & -0.21 & & & \\
\hline Wind Speed & 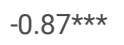 & $-0.79 * \star$ & $-0.74^{\star \star}$ & -0.53 & 0.11 & $-0.66^{\star}$ & $-0.68^{*}$ & $-0.73^{\star *}$ & -0.08 & -0.20 & & \\
\hline $\begin{array}{l}\text { Wind } \\
\text { Direction }\end{array}$ & $-0.72^{\star \star}$ & $-0.82^{\star \star \star}$ & $-0.68^{*}$ & -0.29 & 0.49 & -0.51 & -0.30 & $-0.73^{\star \star}$ & -0.33 & -0.21 & 0.48 & \\
\hline $\begin{array}{l}\text { Air } \\
\text { Temperature }\end{array}$ & $-0.67^{\star}$ & $-0.87^{\star \star \star}$ & -0.72 ** & -0.39 & -0.02 & -0.43 & -0.34 & $-0.97 * \star \star$ & -0.32 & -0.17 & $0.63^{*}$ & 0.61 \\
\hline $\begin{array}{l}\text { Relative } \\
\text { Humidity }\end{array}$ & $-0.85^{\star \star \star}$ & $-0.89 * \star \star$ & $-0.77 * \star$ & -0.52 & 0.14 & $-0.58^{\star}$ & $-0.60 *$ & $-0.92^{\star \star \star}$ & -0.24 & -0.23 & $0.92^{\star \star \star}$ & $0.5 i$ \\
\hline Radiation & $-0.65^{\star}$ & -0.51 & -0.47 & -0.42 & $0.58^{\star}$ & $-0.63^{\star}$ & $-0.59 *$ & -0.37 & -0.09 & -0.28 & $0.70 *$ & $0.5<$ \\
\hline
\end{tabular}


Table 3

Pearson's Correlation among Different Parameters at North Nazimabad

\begin{tabular}{|c|c|c|c|c|c|c|c|c|c|c|c|c|}
\hline & $\begin{array}{l}\text { Nitric } \\
\text { Oxide }\end{array}$ & $\begin{array}{l}\text { Nitrogen } \\
\text { Dioxide }\end{array}$ & $\begin{array}{l}\text { Nitrogen } \\
\text { Oxides }\end{array}$ & Methane & $\begin{array}{l}\text { Non- } \\
\text { methane } \\
\text { HCs }\end{array}$ & $\begin{array}{l}\text { Total } \\
\text { Hydrocarbons }\end{array}$ & $\begin{array}{l}\text { Carbon } \\
\text { Monoxide }\end{array}$ & $\begin{array}{l}\text { Sulfur } \\
\text { Dioxide }\end{array}$ & Ozone & $\begin{array}{l}\text { Methane } \\
\text { Carbon }\end{array}$ & $\begin{array}{l}\text { Wind } \\
\text { Speed }\end{array}$ & $\begin{array}{l}\text { Wind } \\
\text { Direct }\end{array}$ \\
\hline $\begin{array}{l}\text { Nitrogen } \\
\text { Dioxide }\end{array}$ & $0.64 *$ & & & & & & & & & & & \\
\hline $\begin{array}{l}\text { Nitrogen } \\
\text { Oxides }\end{array}$ & $0.64^{\star}$ & $0.77 * \star$ & & & & & & & & & & \\
\hline Methane & 0.48 & 0.30 & 0.54 & & & & & & & & & \\
\hline $\begin{array}{l}\text { Non-Methane } \\
\mathrm{HCs}\end{array}$ & -0.14 & -0.13 & -0.29 & 0.02 & & & & & & & & \\
\hline $\begin{array}{l}\text { Total } \\
\text { Hydrocarbons }\end{array}$ & $0.67 *$ & $0.62^{*}$ & 0.51 & 0.07 & -0.15 & & & & & & & \\
\hline $\begin{array}{l}\text { Carbon } \\
\text { Monoxide }\end{array}$ & $0.63^{*}$ & $0.75^{\star \star}$ & $0.94^{\star \star \star}$ & 0.55 & -0.36 & 0.35 & & & & & & \\
\hline $\begin{array}{l}\text { Sulfur } \\
\text { Dioxide }\end{array}$ & -0.51 & -0.19 & -0.34 & 0.05 & -0.09 & -0.55 & -0.15 & & & & & \\
\hline Ozone & 0.04 & 0.13 & 0.41 & 0.32 & 0.44 & -0.05 & 0.25 & -0.39 & & & & \\
\hline $\begin{array}{l}\text { Methane } \\
\text { Carbon }\end{array}$ & 0.35 & 0.38 & $0.68^{*}$ & 0.31 & -0.17 & 0.54 & $0.59 *$ & -0.35 & 0.31 & & & \\
\hline Wind Speed & -0.45 & $-0.66^{*}$ & -0.81 ** & -0.35 & -0.11 & -0.27 & $-0.74^{\star *}$ & 0.39 & $-0.60 *$ & -0.46 & & \\
\hline $\begin{array}{l}\text { Wind } \\
\text { Direction }\end{array}$ & -0.28 & $-0.65^{\star}$ & $-0.83^{\star \star \star}$ & -0.48 & 0.27 & -0.36 & $-0.82^{\star \star \star}$ & -0.12 & -0.30 & $-0.64^{*}$ & $0.59 *$ & \\
\hline $\begin{array}{l}\text { Air } \\
\text { Temperature }\end{array}$ & -0.06 & -0.38 & $-0.70 *$ & -0.51 & 0.02 & -0.11 & $-0.67^{*}$ & -0.12 & -0.55 & $-0.60^{*}$ & $0.60 *$ & $0.90 *$ \\
\hline $\begin{array}{l}\text { Relative } \\
\text { Humidity }\end{array}$ & -0.40 & $-0.61^{\star}$ & -0.78 ** & -0.46 & -0.07 & -0.23 & -0.74 ** & 0.14 & $-0.61^{*}$ & -0.31 & $0.77^{\star \star}$ & $0.77^{*}$ \\
\hline Radiation & $-0.85^{\star \star \star}$ & $-0.75^{\star \star}$ & -0.79 ** & -0.53 & 0.16 & -0.52 & $-0.83^{\star \star \star}$ & 0.25 & -0.07 & -0.43 & $0.58^{\star}$ & 0.57 \\
\hline
\end{tabular}

Nitric oxide and nitrogen dioxide were positively correlated $(\mathrm{p}<0.05)$ with total hydrocarbons at DHA and North Nazimabad. Nitrogen oxides and carbon monoxide are negatively correlated with every meteorological factor at North Nazimabad (Table 3). Nitrogen dioxide and nitrogen oxides are negatively correlated with wind direction and velocity, relative humidity, and radiation only at North Nazimabad. Sulfur dioxide was correlated ( $p<0.01)$ with all the oxides of nitrogen and negatively correlated $(p<0.01)$ with air temperature, wind direction and velocity, and relative humidity only at DHA (Table 2$)$.

Methane and non-methane hydrocarbons did not show any strong association with meteorological factors at all the designated sites. However, methane demonstrated a negative correlation $(p<0.05)$ with air temperature, wind velocity, and relative humidity at Sohrab Goth (Table 1$)$, and non-methane hydrocarbons were found positively correlated $(p<0.05)$ with radiation at DHA (Table 2$)$. Total hydrocarbons were positively correlated $(p<0.05)$ with nitric oxide and nitrogen dioxide at DHA and North Nazimabad. They were negatively correlated $(p<0.05)$ with radiation at Sohrab Goth and with wind velocity, relative humidity, and radiation at DHA.

\section{Discussion}

The results demonstrate that the annual mean concentration of nitrogen dioxide $\left(\mathrm{NO}_{2}\right)$ exceeded its WHO guidelines $\left(40 \mu \mathrm{g} / \mathrm{m}^{3}\right)$ at two sites, viz. Sohrab Goth $\left(61.34 \pm 7.17 \mu \mathrm{g} / \mathrm{m}^{3}\right)$ and DHA $\left(51.17 \pm 16.44 \mu \mathrm{g} / \mathrm{m}^{3}\right)$. The annual mean of $\mathrm{NO}_{2}$ met the guideline at North Nazimabad (Fig. 2). Nonetheless, the average $\left(49.36+18.21 \mu \mathrm{g} / \mathrm{m}^{3}\right)$ of annual mean concentrations of all three sites exceeded the WHO guidelines, taken as a representative mean annual concentration of $\mathrm{NO}_{2}$ for Karachi in this study. The annual $\mathrm{NO}_{2}$ mean value of the city exceeded that of 14 Indian cities. However, the mean $\mathrm{NO}_{2}$ values of six Indian cities transcended Karachi (Guttikunda et al. 2019). Furthermore, the annual mean value of the city understudy did not go beyond those of four Chinese megacities, namely, Beijing, Shanghai, Guangzhou, and Tsuen Wan in Hong Kong (Chan and Yao 2008). These cities are highly motorized and industrialized, which are great contributors to the Chinese economy. Nonetheless, the annu' $\wedge$ al $\mathrm{NO}_{2}$ mean value of Karachi exceeded those of other Chinese cities.

Furthermore, the results show that the annual mean concentration of $\mathrm{SO}_{2}\left(81.22 \pm 17.30 \mu \mathrm{g} / \mathrm{m}^{3}\right)$ exceeded the WHO Guideline $\left(50 \mu \mathrm{g} / \mathrm{m}^{3}\right)$ only at Sohrab Goth. The mean values of the other two sites, namely DHA and North Nazimabad did not go beyond the guidelines. The mean $\mathrm{SO}_{2}$ value of Sohrab Goth also exceeded all the twenty Indian cities (Guttikunda et al. 2019) and the megacities of China (Chan and Yao 2008).

Compressed natural gas (CNG), gasoline, and diesel operate diverse motor vehicles in the city. Diesel runs heavy-duty vehicles, while motorcars and light-duty motor vehicles run either on CNG or gasoline. The diesel contains substantially higher than 500 ppm sulfur, gasoline contains 500 ppm, while CNG has a low concentration of sulfur (Sánchez-Triana et al., 2014). CNG-powered vehicles are predominant in the areas of the middle-income population of the city since it has a lower price, and gasoline-powered motor vehicles commonly operate in the areas of the high-income population. Heavy diesel-powered vehicles, 
particularly 10-wheeler trucks are generally plied in the industrial expanses of the city. Hence, different types of motor vehicles operate in various areas, which causes substantial spatial variation in the ambient concentrations of air pollutants.

10-wheeler trucks and buses are predominantly operated at Sohrab Goth because it is a gateway that connects the city with the rest of the country to supply industrial goods and to provide transportation to the intercity passengers. Furthermore, the neighborhood has a few high sulfur-fuel-operated factories that worsen its air quality (Sánchez-Triana et al., 2014). The heavy-duty diesel-powered vehicles instigated the greatest ambient $\mathrm{SO}_{2}$ concentration at Sohrab Goth, followed by DHA $\left(35.47 \pm 17.09 \mu \mathrm{m} / \mathrm{m}^{3}\right)$ and North Nazimabad $\left(26.50 \pm 7.20 \mu \mathrm{m} / \mathrm{m}^{3}\right)$.

DHA and North Nazimabad are residential areas that do not have industries. Therefore, heavy-duty vehicles infrequently operate in these areas. DHA inhabits mainly a high-income population while the middle-income population resides in North Nazimabad (FBR 2019). Motorcars and light-duty motor vehicles extensively operate in both areas. However, gasoline-powered motor vehicles at DHA and CNG-powered vehicles at North Nazimabad predominantly cater to private and commercial activities. North Nazimabad demonstrated the lowest ambient concentration, which may be due to the dominance of CNG-powered motor vehicles in its vicinity.

High fuel sulfur not only causes SO2 emissions but also restricts the adoption of the latest emission control devices. For instance, a three-way catalytic converter, which controls the emissions of hydrocarbons, carbon monoxide, and nitrogen oxides, cannot function properly in the presence of high sulfur fuel. Fuel Sulfur damages the catalyst that controls the three pollutants. Pakistan adopted Euro II vehicular emission standard in 2009 for gasoline-powered vehicles. After a decade, the country adopted the same standards for diesel-powered vehicles, mainly due to the unavailability of low sulfur fuel. Furthermore, many motor vehicles do not comply with Euro II Emission Standards because of weak regulatory intervention.

Due to these factors, motor vehicles in Karachi emit a higher quantity of oxides of sulfur and nitrogen, all the hydrocarbons, carbon monoxide, and ozone. Barletta et al. (2002) pointed out the leakage of natural gas and liquefied petroleum for the elevation of the methane and non-methane hydrocarbons in the atmosphere of this city. According to them, vehicular exhaust emissions are the most imperative source of ambient hydrocarbons. The developed countries adopted more stringent vehicular emission standards only in the presence of low or zero sulfur fuel in their countries. China and India have reduced sulfur content in their fossil fuel over the last few years, which allowed them to adopt more stringent emission standards for their motor vehicles.

Furthermore, the results demonstrate that some air pollutants are closely related to each other and meteorological factors. The present study reveals that all the nitrogen oxides are closely correlated at all designated sites. Jan et al. (2017) found a similar correlation between various nitrogen oxides when analyzing their data of 98 days air quality of Karachi. They also affirmed a significant correlation of carbon monoxide (CO) with each oxide of nitrogen. The current study demonstrated a similar relation of $\mathrm{CO}$ with all oxides of nitrogen at two study sites.

Meteorological factors, namely, air temperature, wind velocity and direction, relative humidity, and radiation influenced the temporal distribution of ambient concentrations of air pollutants, particularly at DHA, mainly due to its close location to the Arabian Sea. Air temperature, wind velocity and direction, and relative humidity revealed a statistically significant negative correlation with $\mathrm{NO}, \mathrm{NO}_{2}, \mathrm{NOx}$, and $\mathrm{SO}_{2}$ at $\mathrm{DHA}$. All oxides of nitrogen also showed a significant negative correlation with the above-mentioned meteorological factors at Sohrab Goth. However, the meteorological factors did not divulge any correlation with $\mathrm{SO}_{2}$ at Sohrab Goth. It indicates uninterrupted $\mathrm{SO}_{2}$ emission due to the continuous operation of intercity diesel-powered trucks and buses at this site. Carbon monoxide (CO) demonstrated a strong negative correlation with all the meteorological factors only at North Nazimabad, a centrally located in of the city. CO did not show any correlation with any meteorological factor at Sohrab Goth. Nonetheless, it divulged a negative correlation $(p<0.05)$ with wind velocity, relative humidity, and radiation at DHA.

\section{Declarations}

\section{Data Availability Statement:}

Raw data are available on request from the first author. The data are not available on any internet link. Data were generated at the facility available in the Sindh Environmental Protection Agency's permanent and mobile monitoring stations, Karachi, Pakistan.

\section{Competing interests:}

The authors declare no competing interest.

\section{References}

Ali, G., Bao, Y., Ullah, W., Ullah, S., Guan, Q., Liu, X., Li, L., Lei, Y., Li, G., \& Ma, J. (2020). Spatiotemporal trends of aerosol over urban regions in Pakistan and their possible links to meteorological parameters. Atmosphere 11:306.

Barletta, B., Meinardi, S., Simpson, I.J., Khwaja, H.A., Blake, D.R., \& Rowland, S. (2002). Mixing ratios of volatile organic compounds (VOCs) in the atmosphere of Karachi. Atmospheric Environment 36: 3429 - 3443.

Bibi, S., Alam, K., Chishtie, F., Bibi, H., \& Rahman, S. (2017). Temporal variation of black carbon concentration using Aethalometer observations and its relationships with meteorological variables in Karachi, Pakistan. Journal of Atmospheric and Solar-Terrestrial Physics 157-158: 67-77.

Chan, C.K., \& Yao, X. (2008). Air Pollution in megacities in China. Atmospheric Environment 42: 1- 42. 
Chen, T-M., Shofer, S., Gokhale, J. and Kuschner, W.G. (2007). Outdoor air pollution: overview and historical perspective. American Journal of Medical Science 333: $230-234$

Crippa, M., Janssens-Maenhout, G., Dentener, F., Guizzardi, D., Sindelarova, K., Muntean, M., Van Dingenen, R., \& Granier, C. (2015). Forty years of improvement in European air quality: the role of EU policy - industry interplay. Atmospheric Chemistry and Physics, Discussions 15: 2024520265.

FBR, 2019. Federal Board of Revenue, Revenue Department, Government of Pakistan, Statutory Regulatory Order, S.R.O. 837(1)/2019. dated 23rd July 2019. https://download1.fbr.gov.pk/SROs/20197231971722163Karachi2019-07-23(1).pdf

Gulia, S., Khanna, I., Shukla, K., \& Khare M. (2020). Ambient air pollutant monitoring and analysis protocol for low and middle-income countries: An element of comprehensive urban air quality management framework. Atmospheric Environment 222: 117120

Guttikunda, S.K., Nishadh, K.A., \& Jawahar, P. (2019). Air pollution knowledge assessments (APnA) for 20 Indian cities. Urban Climate 27: 124 - 141.

Hao, Y., Peng, H., Temulun, T., Liu, L-Q., Mao, J., Lu, Z-N., \& Chen, H. (2018). How harmful is air pollution to economic development? New evidence from PM 2.5 concentrations of \Chinese cities. Journal of Cleaner Production 172: 743-757.

Hashmi, D.R., Shareef, A., \& Begum, R. (2018). A study of ambient air quality status in Karachi by applying the Air Quality Index (AQI). Pakistan Journal of Scientific and Industrial Research: Physical Science 61A (2): 106-114.

Hayes, R.B., Lim, C., Zhang, Y., Cromar, K., Shao, Y., Reynolds, H.R., Silverman, D.T., Jones, R.R., Park, Y., Jerret, M., Ahn, J., \& Thurston, G.D. (2020). PM2.5 air pollution and cause-specific cardiovascular disease mortality. International Journal of Epidemiology 49: 25-35.

He, J., Gong, S., Yu, Y., Yu, L., Wu, L., Mao, H., Song, C., Zhao, S., Liu, H., Li, X., \& Li, R. (2017). Air pollution characteristics and their relation to meteorological conditions during 2014 - 2015 in major Chinese cities. Environmental Pollution 223: 484 - 496.

Jan, B., Ghayasuddin, S., Hussain, M.A., Yousuzai, M.A.K., Ali, M., \& Nawaz, F. (2017). Analysis of variability of atmospheric pollutants in ambient air metropolitan city Karachi, and environmental sustainability. Journal of Basic and Applied Sciences 13:311-315.

Jassim, M.S., Coskuner, G., \& Munir, S. (2018). Temporal analysis of air pollution and its relationship with meteorological parameters in Bahrain, 2006 -2012. Arabian Journal of Geoscience 11:62.

Kalisa, E., Fadlallah, S., Amani, M., Nahayo, L., \& Habiyaremye, G. (2018). Temperature and air pollution relationship during a heatwave in Birmingham, UK. Sustainable Cities and Society 43: 111-120.

Karachi Metropolitan Corporation, 2021. http://www.kmc.gos.pk/Contents.aspx?id=14 retrieved on $24^{\text {th }}$ March 2021.

Karagiannidis, A., Poupkou, A., Giannaros, T., Giannaros, C., Melas, D., \& Argiriou, A. (2015). The air quality of a Mediterranean urban environment area and its relationship to major meteorological parameters. Water Air Soil Pollut 226: 2239.

Kayes, I., Shahriar, S.A., Hasan, K., Akhtar, M., Kabir, M.M., \& Salam, M.A. (2019). The relationships between meteorological parameters and air pollutants in an urban environment. Global Journal Environmental Science and Management 5: 265 - 278.

Khaniabadi, Y.O., Hopke, P.K., Goudarzi, G., Daryanoosh, S.M., Jourvand, M., \& Basiri, H. (2017). Cardiopulmonary mortality and COPD are attributed to ambient ozone. Environmental Research 152: 336 - 341.

Kottek, M., Grieser, J., Beck, C., Rudolf, B., \& Rubel, F. (2006). World map of the Koppen-Greiger climate classification. Meteorol Z15:259-263.

Lelieveld, J., Evans, J.S., Fnais, M., Giannadaki, D., \& Pozzer, A. (2015). The contribution of outdoor air pollution sources to premature mortality on a global scale. Nature 525: 367-384.

Li, H., Wu, J., Wang, A., Li, X., Chen, S., Wang, T., Amsalu, E., Gao, Q., Luo, Y., Yang, X., Wang, W., Guo, J., Guo, Y., \& Guo, X. (2018). Effects of ambient carbon monoxide on daily hospitalizations for cardiovascular disease: a time-stratified case-crossover study of 460,938 cases In Beijing, China from 2013 to 2017. Environmental Health 17: 82

Li, X., Jin, L., \& Kan, H. 2019. Air pollution: a global problem that needs local fixes. Nature, 570: 437-439.

Namvar, Z., Yunesian, M., Shamsipour, M., Hassanvand, M.S., Naddafi, K., \& Shahhosseini, E. (2020). Cross-sectional associations between ambient air pollution and respiratory signs and symptoms among young children in Tehran. Atmospheric Environment 223:117268.

Pearce, J. L., Beringer, J., Nicholls, N., Hyndman, R.J., \& Tapper, N.J. (2011). Quantifying the influence of local meteorology on air quality using generalized additive models. Atmospheric Environment 45: 13281336.

Sánchez-Triana, E., Enriquez, S., Afzal, J., Nakagawa, A., \& Khan, A.S. (2014). Cleaning Pakistan's Air: Policy Options to Address the Cost of Outdoor Air Pollution. The World Bank, Washington DC. https://openknowledge.worldbank.org/handle/10986/18887

Shams, Z.I. \& Beg, M.A.A. (2001). Carbon monoxide concentration in the streets of Karachi. Indian Journal of Environmental Protection 20(3):216-224. 
Turner, M.C., Anderson, Z.J., Baccarelli, A., Diver, W.R., Gapstur, S.M., Pope, C.A., Prada, D., Samet, J., Thurston, G., \& Cohen, A. (2020). Outdoor air pollution and cancer: An overview of the current evidence and public health recommendations. CA Cancer 70: $460-479$.

WHO http://www.emro.who.int/pak/programmes/environmental-health.html

Wu, Y.-C., Shiledar, A., Li, Y.-C., Wong, J., Feng, S., Chen, X., Chen, C., Jin, K., Janamian, S., Yang, Z., Ballard, Z.S., Gorocs, Z., Feizi, A., \& Ozcan, A. (2017). Air quality monitoring using mobile microscopy and machine learning. Light: Science \& Applications 6: e17046.

Zhang, F., Shi, Y., Fang, D., Ma, G., Nie, C., Krafft, T., He, L., \& Wang, Y. (2020). Monitoring history and change trends of ambient air quality in China during the past four decades. Journal of Environmental Management 260: 110031.

Zhang, H., Wang, Y., Hu, j., Ying, Q., \& Hu, X-M, (2015). Relationships between meteorological parameters and criteria air pollutants in three megacities in China. Environmental Research 140: 242-254.

Zhang, J.J., Wei, Y., \& Fang, Z., (2019). Ozone pollution: a major health hazard worldwide. Frontiers in Immunology 10: 2518.

Zhao, Y., Tan, Y., \& Feng, S. (2018). Does reducing air pollution improve the progress of sustainable development in China? Journal of Cleaner Production 272:122759.

\section{Figures}

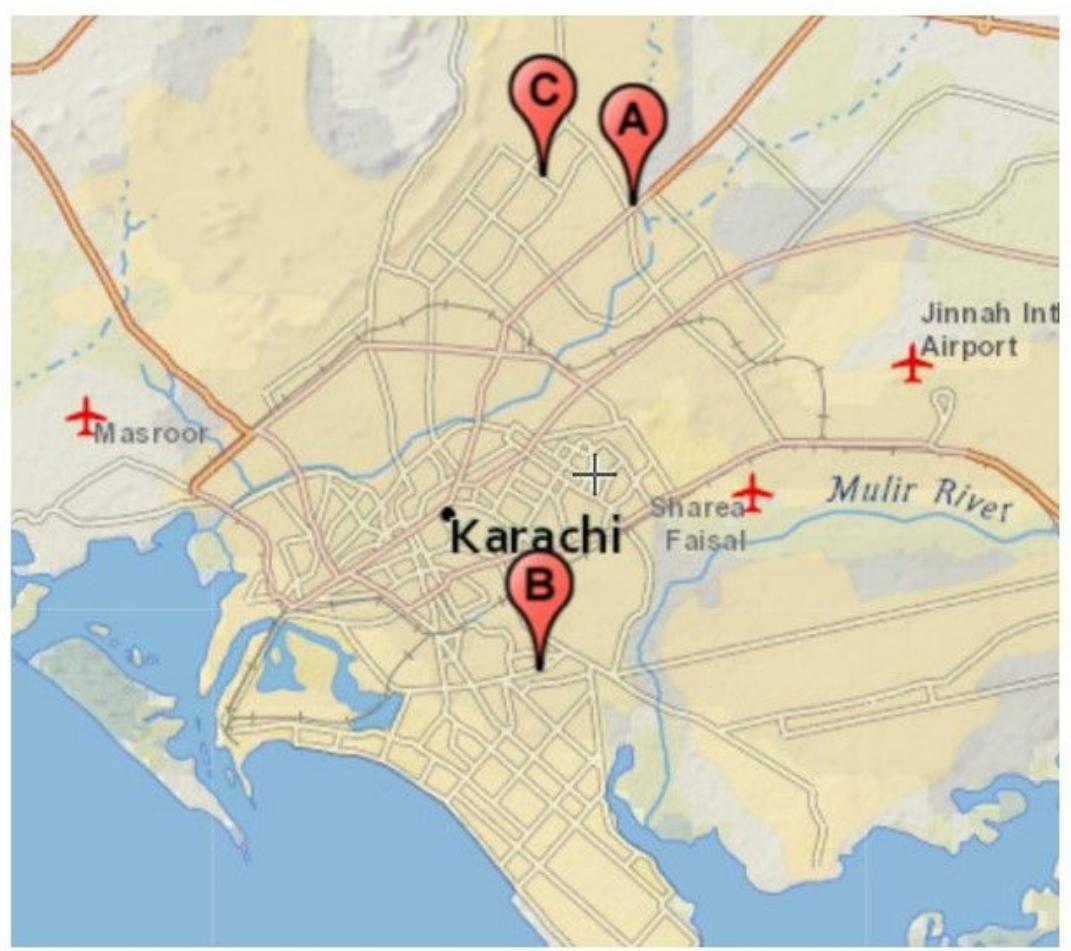

\section{$\sqrt{\text { A }}$ Sohrab Goth $\sqrt[B]{\text { DHA }} \sqrt{\text { North Nazimabd }}$}

\section{Figure 1}

Air Pollutants Sampling Sites in Karachi

\section{Figure 2}

Annual mean concentrations of sulfur dioxide (SO2) and nitrogen dioxide (NO2) at Sohrab Goth (SG), Defense Housing Authority (DHA), and North Nazimabad (NN) and their WHO guidelines. 


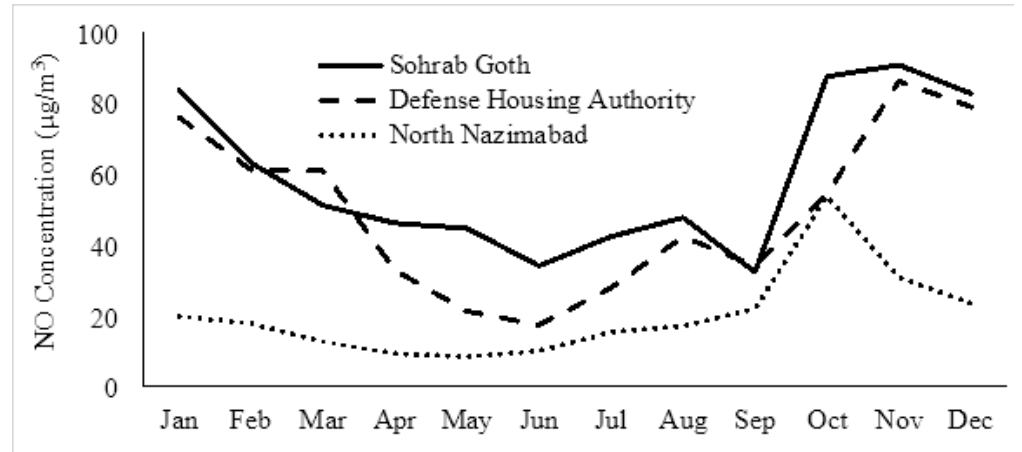

Figure 3

Nitric oxide concentrations of different sites differ statistically $(p<0.001)$

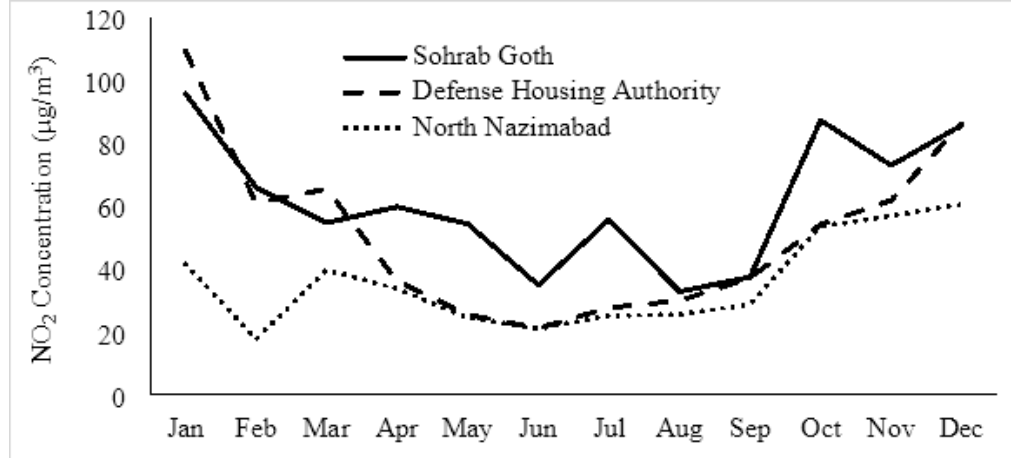

Figure 4

Nitrogen dioxide concentrations of different sites differ statistically $(p<0.05)$

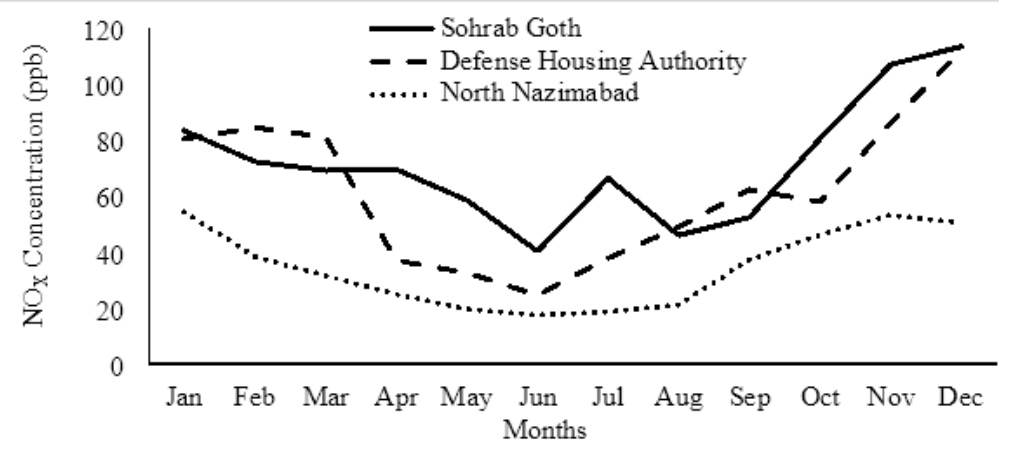

\section{Figure 5}

Nitrogen oxides concentrations of different sites differ statistically $(p<0.001)$

\section{Figure 6}

Ozone concentrations do not differ statistically. 


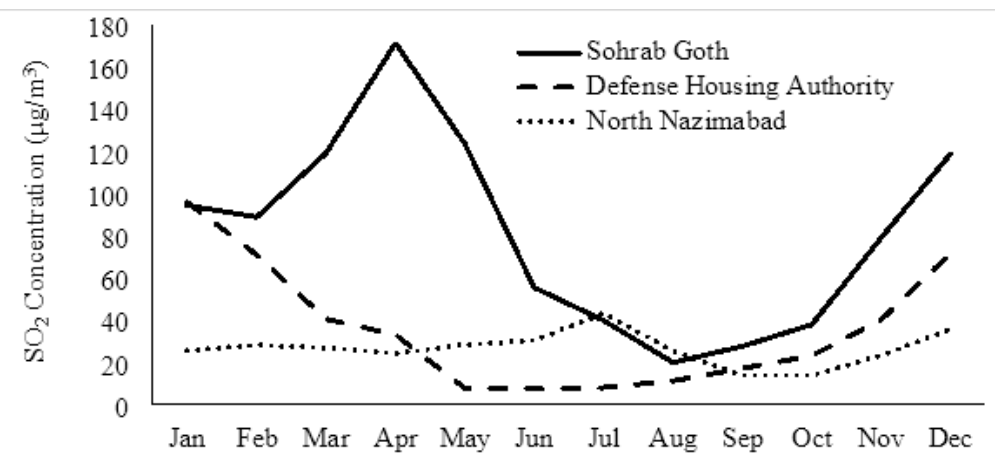

Figure 7

Sulfur dioxide concentrations of different sites differ statistically $(p<0.001)$

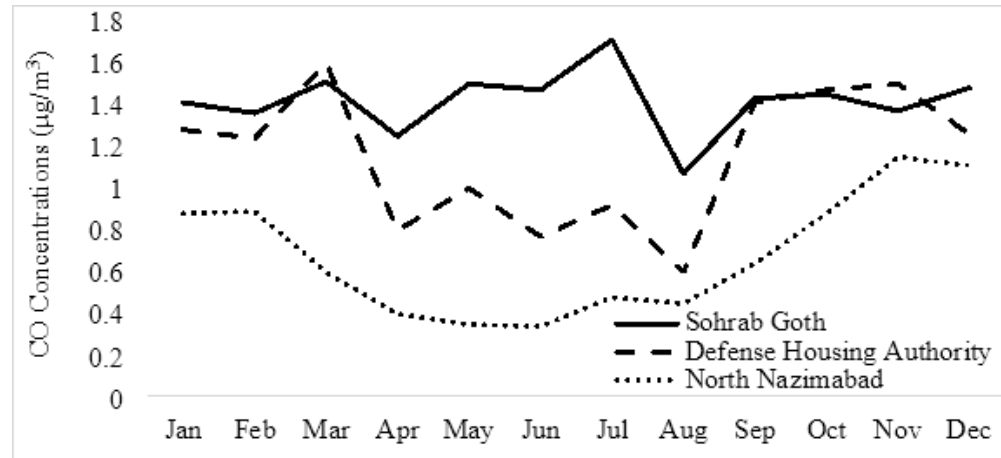

Figure 8

Carbon monoxide concentrations of different sites differ statistically $(p<0.001)$

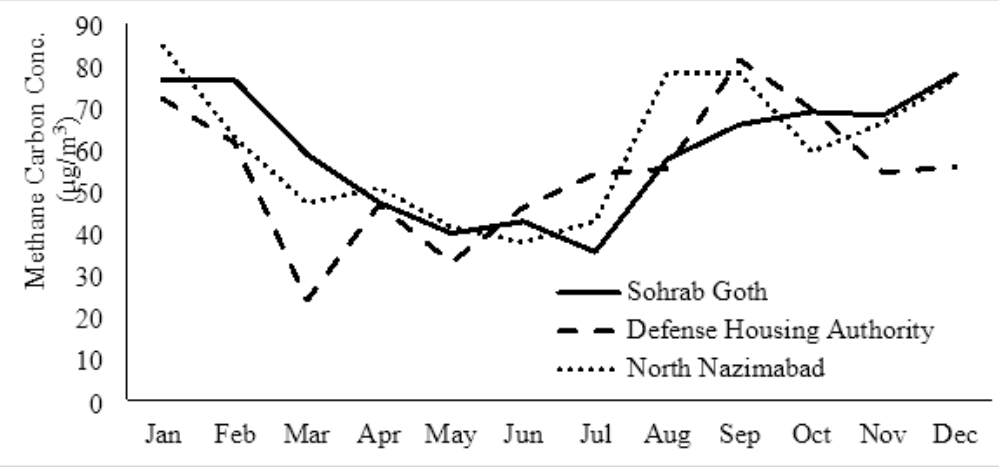

Figure 9

Methane carbon concentrations of different sites do not differ

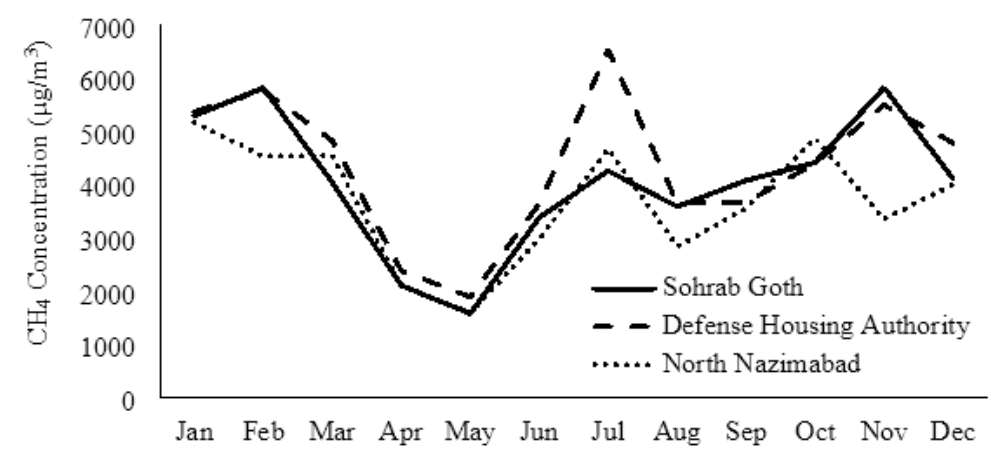

Figure 10

Methane concentrations of different sites do not differ. 


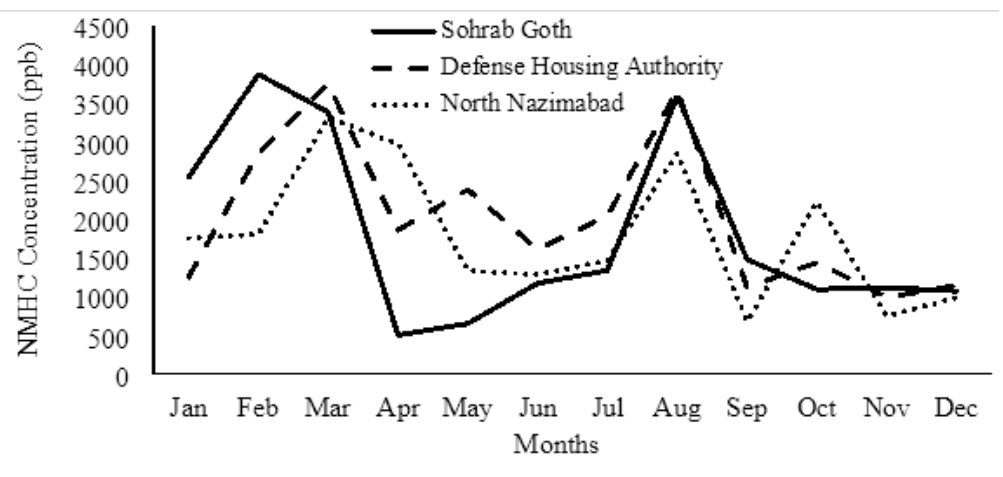

Figure 11

Non-methane hydrocarbon concentrations of different sites do not differ.

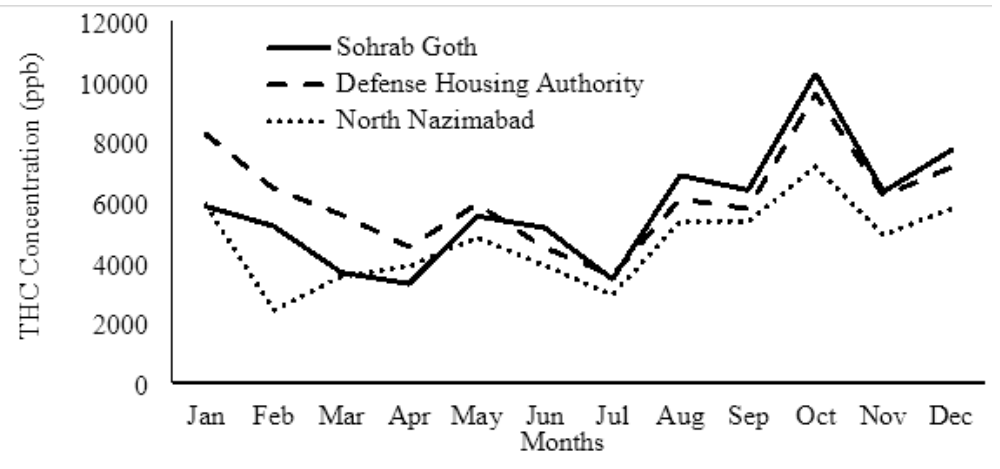

Figure 12

Total hydrocarbons do not differ among different sites.

\section{Figure 13}

Boxplot for six pollutants at Sohrab Goth (SG), DHA, and North Nazimabad (NN). 1. *Unit of NOx: ppb

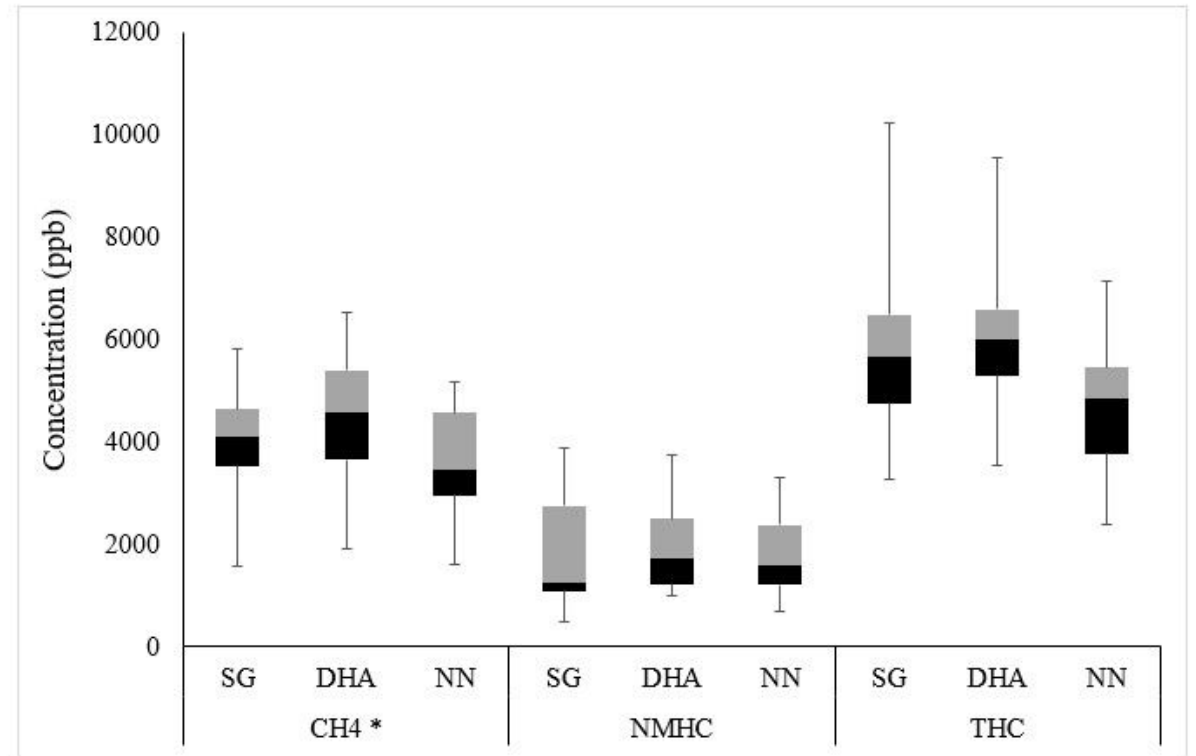

Figure 14

Boxplot for 3 pollutants at Sohrab Goth (SG), DHA, and North Nazimabad (NN). *Unit of CH4: $\mu \mathrm{g} / \mathrm{m} 3$

Figure 15

Page $13 / 14$ 
Boxplot for carbon monoxide at Sohrab Goth (SG), DHA, and North Nazimabad (NN).

Page $14 / 14$ 